\title{
Difficulties in diagnosis of bovine tuberculosis in suggestive lesions on post-mortem inspection in carcasses
}

\author{
Dificuldades no diagnóstico da tuberculose bovina em lesões \\ sugestivas na inspeção post-mortem em carcaças
}

\begin{abstract}
Márcio Junio Lima Siconelli*, David Attuy Vey-da-Silva², Andressa de Souza-Pollo ${ }^{3}$ \& Karina Paes Bürger ${ }^{4}$ 'Veterinary, Residency in Preventive Veterinary Medicine and Public Health (FCAV/J - Unesp), MSc student in the Basic and Applied Immunology Program. Laboratório de Virologia Molecular- LVM, Centro de Pesquisa em Virologia- CPV, Departamento de Bioquímica e Imunologia, Faculdade de Medicina de Ribeirão Preto - FMRP, Universidade de São Paulo USP, Ribeirão Preto, SP, Brasil

Veterinary, MSc, PhD student in Experimental Epidemiology Applied to Zoonoses Program. Departamento de Medicina Veterinária Preventiva e Saúde Animal - VPS, Faculdade de Medicina Veterinária e Zootecnia - FMVZ, Universidade de São Paulo - USP, Campus Fernando Costa, Pirassununga, SP, Brasil

${ }^{3}$ Agronomist Engineer, PhD, Assistent of Academic Support IV. Laboratório de Epidemiologia Molecular, Departamento de Medicina Veterinária Preventiva e Reprodução Animal, Faculdade de Ciências Agrárias e Veterinárias - FCAV, Universidade Estadual Paulista - UNESP, Jaboticabal, SP, Brasil

${ }^{4}$ Veterinary, PhD, Professor. Departamento de Medicina Veterinária Preventiva e Reprodução Animal, Faculdade de Ciências Agrárias e Veterinárias - FCAV, Universidade Estadual Paulista - UNESP, Jaboticabal, SP, Brasil
\end{abstract}

\begin{abstract}
The bovine tuberculosis is a zoonotic disease with importance to the public health. The post-mortem identification and its fast and accurate diagnosis combined with the epidemiology knowledge are essential to fight against the spread of the disease. Therefore, we aimed to perform the identification of Mycobacterium bovis DNA, the histopathologic characterization of the affected lymph nodes and the detection of acid-fast bacilli (AFB), seeking to compare them. During slaughter of cattle in slaughter plants, under Federal Inspection Service in São Paulo State, lymph nodes with tuberculosis-like lesions were collected and labeled in duplicate. One was intended to the histopathology characterization (hematoxylin-eosin-HE, staining for lesion characterization and the Ziehl-Neelsen-ZN, staining to detect the AFB). The other sample was separated to the M. bovis DNA identification by Polymerase Chain Reaction (PCR) and nested PCR. The bacterial DNA could be identified in 20.84\% (10/48) of the collected lymph nodes. However, when the results were compared with more sensitive tests (nested PCR) and cheapest ones (histopathological characterization of lesions by $\mathrm{HE}$ and the $\mathrm{AFB}$ detection by $\mathrm{ZN}$ ), different results were found. When performing nested PCR technique was applied in PCR negative samples (38/48), it was found $18.74 \%$ (9/38) more positive samples results. Thus, we could identify the M. bovis DNA in 39.58\% (19/48) of the collected lymph nodes. However, applying the HE staining we characterize 66.67\% (32/48) of the samples as tuberculosis-like lesions and ZN staining detected 54.17\% (26/48) of AFB. A multi-step approach involving diferents testa, molecular and histopathological, can help to identify M. bovis in tissues, like lymph nodes, from naturally infected bovines and allows a broader epidemiological approach.
\end{abstract}

Keywords: cattle, PCR, M. bovis, zoonosis.

\section{Resumo}

A tuberculose(TB) bovina é uma zoonose de importância para a saúde pública. Aidentificação post-mortem e seu diagnóstico rápido e preciso combinados ao conhecimento de sua epidemiologia são fundamentais para combater a disseminação da doença. O estudo objetivou realizar a identificação do DNA do Mycobacterium bovis, a caracterização histopatológica dos linfonodos afetados e a detecção de bacilos álcool-ácidos resistentes (BAARs), comparando-os. Durante o abate de bovinos em matadouros-frigoríficos sob Serviço de Inspeção Federal (SIF) no Estado de São Paulo, linfonodos com lesões sugestivas de TB foram colhidos e identificados, em duplicata. Uma foi destinada à caracterização histopatológica (coloração de hematoxilina-eosina - HE, para caracterização da lesão e a coloração de Ziehl-Neelsen - ZN, para detectar os BAARs). A outra amostra foi separada para a identificação do DNA do $M$. bovis pela Reação em Cadeia pela Polimerase (PCR) e nested PCR. O DNA bacteriano pode ser identificado em 20,84\% (10/48) dos linfonodos coletados. Entretanto, quando os resultados foram comparados com testes mais sensíveis
How to cite: Siconelli, M. J. L., Vey-da-Silva, D. A., Souza-Pollo, A., \& Bürger, K. P. (2018) Difficulties in diagnosis of bovine tuberculosis in suggestive lesions on post-mortem inspection incarcasses. Brazilian Journal of Veterinary Medicine, 40, e002518. doi: 10.29374/2527-2179.bjvm002518

Conflict of interests: No conflict of interests declared concerning the publication of this article.

Received: July 11, 2017.

Accepted: October 24, 2017.

The study was carried out at Departamento de Medicina Veterinária Preventiva e Reprodução Animal, Faculdade de Ciência Agrária e Veterinárias - FCAV, Universidade Estadual Paulista - UNESP, Campus Jaboticabal, Jaboticabal, SP, Brasil.

\section{*Correspondence}

Márcio Junio Lima Siconelli

Departamento de Medicina Veterinária Preventiva e Reprodução Animal, Faculdade de Ciências Agrárias e Veterinárias - FCAV, Universidade Estadual Paulista - UNESP Via de Acesso Prof. Paulo Donato Castellane, s/n CEP 14884-900 - Jaboticabal (SP), Brasil E-mail:marcio_siconelli@outlook.com

Copyright Siconelli et al. This is an Open Access article distributed under the terms of the Creative Commons Attribution Non-Commercial License which permits unrestricted non-commercial use, distribution, and reproduction in any medium provided the original work is properly cited. 
(nested PCR) e testes com menor custo (a caracterização histopatológica das lesões e a detecção dos BAARs), foram encontrados resultados diferentes. Quando as amostras PCR negativas (38/48) foram submetidas à técnica de nested PCR, encontrou-se 18,74\% (9/38) a mais de positividade. Portanto, pode-se identificar o DNA do M. bovis em 39,58\% (19/48) dos linfonodos coletados. Entretanto, empregando-se a coloração HE pode-se caracterizar 66,67\% (32/48) das amostras como lesões sugestivas de tuberculose e pela coloração de ZN foram detectados 54,17\% (26/48) de BAARs. Uma abordagem envolvendo diferentes testes, como moleculares e histopatológicos, pode ajudar a identificar o $M$. bovis em tecidos, como linfonodos, de bovinos naturalmente infectados e permitir uma abordagem epidemiológica mais ampla.

Palavras-chave: bovino, PCR, M. bovis, zoonose.

\section{Introduction}

Bovine tuberculosis (TB) is a zoonosis of chronic evolution and debilitating effect, caused by Mycobacterium bovis, which primary host is the bovine species. However, several species of mammals, including humans, are also susceptible to be infected by this microorganism. Pathologically, this disease is characterized by the formation of a granulomatous lesion, nodular appearance, called "tuber" (Furlanetto et al., 2012).

Sanitary inspection of meat is essential for public health by removing pathogen-borne meat from the circulation and providing statistical and nosogeographic data, which allow the implementation of disease control and eradication programs (Ungar \& Germano, 1992).

The diagnosis of TB can be made by direct and indirect methods. The direct ones involve the detection and identification of the etiologic agent in the biological material, resulting in more accurate diagnoses. The indirect investigates an immune response of the host to the etiological agent, which can be humoral (production of circulating antibodies) or cellular (mediated by lymphocytes and macrophages) (Brasil, 2006).

Microbiological culture of Mycobacterium spp., which is the gold standard, allows the identification of isolated mycobacteria, as well as the performance of antibiotic sensitivity tests. The main diagnostic disadvantages are the very prolonged time between inoculation and the emergence of macroscopically visible colonies (24 to 40 days, up to 90 days), because of the requirement of viable organisms to be carried out. It demands adequate manipulation of the clinical specimens (Koneman et al., 2001), which carries a high risk of human infection and also the need for alaboratory structure with biosafety level 03 (NBO3). These points make it unfeasible and more difficult to diagnose by this technique.

As an alternative, we can use histopathological analyzes, performing the tissue characterization of the lesion by hematoxylin-eosin (HE) staining and the detection of AFBby Ziehl-Neelsen staining (ZN) (Brasil, 2008). HE staining allows verifying the presence of granuloma, which is considered suggestive of tuberculosis (Andrade et al., 1991), conversely, ZN is specific for confirming the presence of AFB (Brasil, 2008).

Rapid diagnosis of Mycobacterium spp. in clinical samples can also be performed by PCR assays (Polymerase Chain Reaction). This diagnostic practice using tissue has been used in theinvestigation of tuberculosis in some countries (Taylor et al., 2001, 2007; Furlanetto et al., 2012), although they do not yet have a great impact on diagnostic methods performed in developing countries such as Brazil (Araújo et al., 2014).

Interest in molecular methods has intensified due to the difficulties in the diagnosis of the disease in animals, mainly because of limitations in the sensitivity and specificity of the skin reaction test and the long period to confirm the presence of the agent by bacteriological methods (Roring et al., 2000; Zanini et al., 2001).

Therefore, the objective of this study was to perform the post-mortem diagnosis of bovine tuberculosis from lymph nodes with lesions suggestive of this disease, detected and collected during sanitary inspection in slaughterhouses, with the Federal Inspection Service (SIF) of the northeast region of São Paulo State.

\section{Material and methods}

\section{Samples}

Samples were collected from 48 adult cattle slaughtered in slaughterhouses under SIF with tissue lesions suggestive of tuberculosis in lymph nodes. These samples were collected in duplicates, identified and stored in universal collection containers for later histopathological characterization 
and identification of AFB and $M$. bovis DNA. One aliquot was placed in $10 \%$ buffered formaldehyde solution, which was kept at room temperature for later inclusion of the fragments in paraffin blocks, followed by the preparation of the slides for histopathological characterization and identification of the AFB. The other samples were frozen at $-20^{\circ} \mathrm{C}$ for further molecular analysis.

\section{Molecular diagnosis}

The samples with lesions suggestive of tuberculosis were thawed for the chemical extraction of bacterial DNA from a protocol optimized by the Laboratory of Veterinary Epidemiology of the Department of Preventive Veterinary Medicine and Animal Reproduction of FCAV/Unesp/Jaboticabal/SP. DNA quality was measured by obtaining the absorbance ratio of each sample at wavelengths of 260 and $280 \mathrm{~nm}$, with desirable values ranging from 1.8 to 2.0 (Sambrook \& Russel, 2001), with a NanoDrop-1000 ${ }^{\circledR}$ spectrophotometer. The integrity of the obtained DNA was visualized by $1 \%$ (w/v) agarose gel electrophoresis.

To identify the presence of $M$. bovis DNA in the lymph nodes, the pair of SCAR markers (Sequenced Characterized Amplified Region Marker) JB21 (5' TCGTCCGCTGATGCAAGTGC 3') and JB22 (5' CGTCCGCTGACCTCAAGAAG 3'), for amplification of a specific 500 bp DNA fragment located within the 4,999 bp genomic region at the end of a putative gene called RvD1-Rv2031c, which is not present in other species of mycobacteria (Rodriguez et al., 1995).

The PCR that enabled such amplification was composed of buffer $1 \mathrm{x}, 2 \mathrm{mM}$ of $\mathrm{MgCl}_{2}, 0.2 \mathrm{mM}$ of dNTPs, $1 \mathrm{U}$ of Taq DNA polimerase, 5 pmol of each primer, $1.2 \mu \mathrm{L}$ of total genomic DNA and $20 \mu \mathrm{L}$ of sterile pure water q.s.p. The reaction occurred in a Veriti ${ }^{\circ}$ thermocycler programmed to cycle at $95^{\circ} \mathrm{C}$ for 3 minutes, 45 cycles at $94^{\circ} \mathrm{C}$ for 40 seconds, $60^{\circ} \mathrm{C}$ for 40 seconds, and $72^{\circ} \mathrm{C}$ for 1 minute, and to conclude, a cycle of 10 minutes at $72^{\circ} \mathrm{C}$. The PCR product was subjected to $1 \%$ (w/v) agarose gel electrophoresis containing ethidium bromide $(0.5 \mu \mathrm{g} / \mathrm{mL})$ and $1 \mathrm{~kb}$ molecular size standard Plus DNA Ladder. The gel was visualized under UV light on photo-documentation equipment GEL DOC XR'.

Due to previous knowledge about the clinical samples, in the case of paucibacillary ones, nested PCR was performed, which is a molecular analysis characterized as a modification of the conventional PCR with the objective of increasing the sensitivity and detection of the genetic material of a certain agent when in small amount in the extraction (Portillo-Gómez et al., 2000; Rebollo et al., 2006). For this purpose, the same protocol as above was used, and the PCR product was added instead of the extracted DNA.

The standard strain of M. bovis (IB2-M. bovis AN5) was used as a positive control in molecular tests.

\section{Histopathological diagnosis}

Both the histopathological characterization and the identification of the AFB were performed at the Laboratory of Histopathology of the Department of Veterinary Pathology of FCAV/Unesp/Jaboticabal/SP. Each tissue fragment was included in paraffin after fixation and cut in the thickness of five micrometers for the preparation of two slides per animal, one stained by hematoxylin-eosin and the other submitted to the Ziehl-Neelsen staining (Behmer et al., 1976). Each group of staining was composed of slides of cases to be evaluated, as well as two slides for positive and negative control. Hematoxylin-eosin stain allowed characterizing histopathological changes, which gives a suggestive diagnosis of tuberculosis to the lesion. On the other hand, the Ziehl-Neelsen staining makes possible the detection, when present, of the AFB.

\section{Data analysis}

The sensitivity and specificity, as well as the confidence intervals (CI) and Youden index were calculated according to Thrusfield (2005). The concordance between the results was calculated using the kappa coefficient (Taylor, 1992) and the results interpreted according to Pereira (2002). The calculations were performed using the EpiR package of statistical software R. 


\section{Ethics committee}

This study was not submitted to the analysis of the Committee on Ethics in Animal Use (CEUA), since the fragments used were taken from the carcass of animals already slaughtered in the routine of slaughterhouses under Federal Inspection Service (SIF), respecting all the processes and standards of animal welfare, guided by legislation: Regulation of Industrial and Sanitary Inspection of Products of Animal Origin (RIISPOA), Decree n 30,691, of March 29, 1952 (Brasil, 1952); Normative Instruction $n^{\circ} 3$ of January 17, 2000 (Brasil, 2000) and Normative Instruction n 56 of November 6, 2008 (REBEM) (Brasil, 2008).

\section{Results and discussion}

\section{Molecular diagnosis}

DNA of the 48 samples was extracted with desirable quality and integrity (Sambrook \& Russel, 2001). The sample tested for the amplification conditions of the PCR product of $495 \mathrm{bp}$, indicating the presence of $M$. bovis showed amplification of a band of the same molecular size as that presented by the standard strain of $M$. bovis, indicating high sensitivity of the technique. Out of the 48 samples tested in the PCR, only 20.84\% (10/48) were considered positive (Figure 1).

PCR allowed the identification of $M$. bovis DNA in 7\% (14/198) of bovine tissue samples (Furlanetto et al., 2012). However, Cardoso et al. (2009), reported that 54.5\% (18/33) of bovine lymph node samples analyzed were considered positive for $M$. bovis to PCR. These authors infer that the amount of DNA used interferes with the sensitivity of the test since they were able to increase the number of samples considered positive by up to $15 \%$, by doubling or tripling the amount of DNA used in PCR.

Several factors may interfere with the reaction, especially when using clinical samples from granulomatous lesions with suppurative and inflamed tissue and at different stages of bacterial infection, subject to the action of possible inhibitors of the reaction. Jordão-Junior (2004) did not succeed in the molecular detection of $M$. bovis from DNA extracted from clinical samples. Ayele et al. (2004) emphasized the need for standardization for molecular tests applied directly on lesions suggestive of tuberculosis and other clinical samples for the test to be reliable.

Schrader et al. (2012) listed different classes of inhibitors present in several types of samples, among them clinical samples, highlighting the presence of blood, hemoglobin, antibodies, presence of ions, cell debris, proteins, as well as many other components that are used or are present during the preparation of the reaction, such as organic detergents and even the talc in the gloves. The lesions suggestive of tuberculosis, considered granulomatous, are due to an intense activation of the immune system of the host organism against the pathogen. The caseous content is rich in inhibitors in its composition, especially when the lesions are calcified and with a

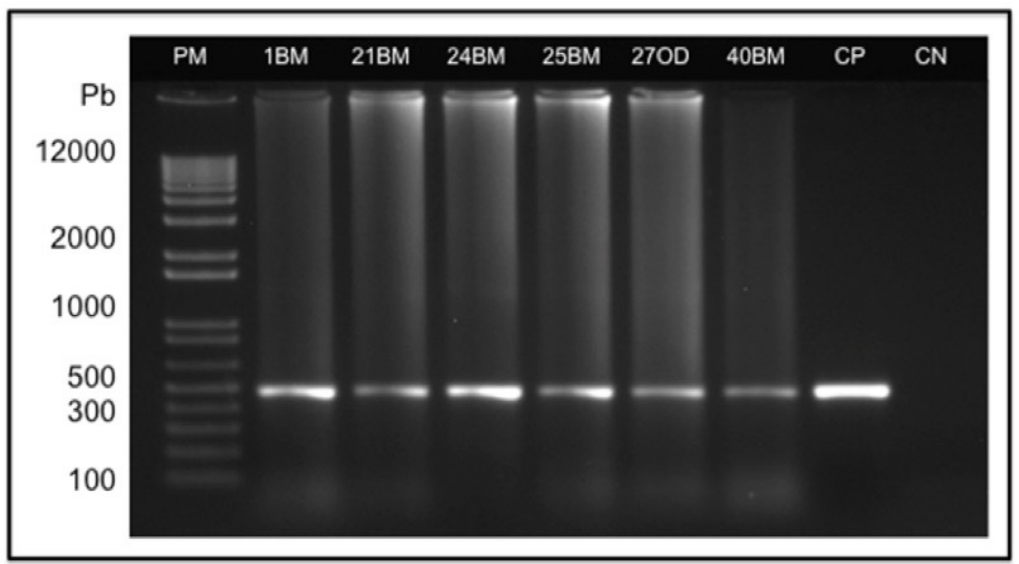

Figure 1. Agarose gel showing bands corresponding to the amplification of the PCR product specific for $M$. bovis from DNA extracted from lesions suggestive of bovine tuberculosis, obtained in slaughterhouses under SIF, during post-mortem inspection. PM: standard molecular size 1kb Plus DNA Ladder (Invitrogen). CP: positive control. CN: negative control. 
longer evolution, requiring good conservation and use of methods that circumvent this problem (Abu Al-Soud \& Râdström, 1998).

Therefore, in order to increase the identification of $M$. bovis in more samples, only the negative ones in PCR were submitted to nested PCR, and the positive ones were considered as positive also in the nested PCR. The number of positive samples increased from $20.84 \%$ (10/48) to 39.58\% (19/48) when applying the technique of nested PCR. Araújo et al. (2014), when evaluating tissue lesions of 131 bovines and buffaloes, obtained $38.2 \%$ of positive samples in nested PCR. Although the aim of its amplification has been the region TbD1 (genes mmpS6 and mmpL6), which is also present in other mycobacteria and could cause cross-detection between species, the authors found a number of positive samples similar to the found in the present study.

Costa et al. (2013) also used a primer insertion sequence different from that used in this study (IS6110), but obtained a similar value (39.1\%) to that of nested PCR positive samples when evaluating tissues with suggestive lesions in 69 bovines. Such data corroborate the information that there are several factors interfering in the PCR reactions and generating more or less identification.

In spite of these possible alterations in the reactions, which may lead to divergence in the results, the use of the nested PCR technique assists in the diagnosis of several diseases, generates more reliable data, contributes to the proper destination of the infected animal and avoids unnecessary losses. In addition to being promising in animal diagnosis, this molecular technique may also improve the sensitivity of tuberculosis diagnosis in humans.

\section{Histopathological characterization}

In histopathological characterization by HE staining, 66.67\% (32/48) were considered characteristic of tuberculosis (Figure 2A), with typical granuloma organized and, according to Arckermann (2013), this type of lesion, TH1 (tuberculoid), is commonly described in cattle, humans and non-human primates, all related to agents of the Mycobacterium tuberculosis complex, with specific epidemiological significance due to pathogenicity. Authors as Jones et al. (2000) and França et al. (2013) describe tuberculous lesions containing areas of caseous necrosis (with dehydrated and dense content) with central dystrophic calcification, surrounded by giant Langhans cells, mononuclear inflammatory infiltrate (macrophages and lymphocytes), and epithelioid cells. In addition, this immune complex is enveloped by a scar tissue connective capsule, which function is to contain the dispersion of the agent to other tissues. This description corroborates the present study. They also report that these lesions also have low mycobacterial load in their interior, because the cells of the immune system cause their destruction, releasing reactive oxygen, degrading even existing genetic material (Jones et al., 2000; França et al., 2013).

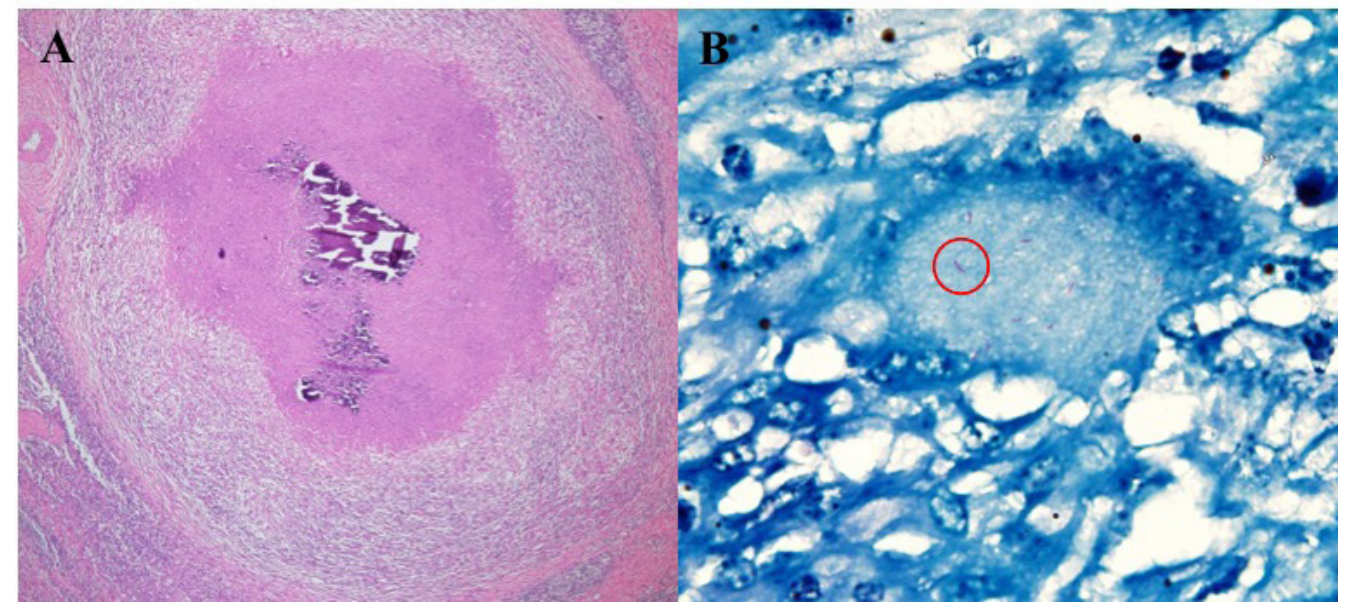

Figure 2. Lesions suggestive of bovine tuberculosis, obtained in slaughterhouses, under SIF, during post-mortem inspection. (A) Characteristic granuloma of tuberculosis, presence of central area with dystrophic calcification, subsequent necrosis, surrounded by inflammatory infiltrate composed mainly of macrophages. HE staining, 4x magnification. (B) Cut displaying AFB (circled) in the cytoplasm of a giant Langhans cell. Circle in red showing the colored AFB. ZN stain, increase of 100x. 
Differently, the lepromatous TH2-type granulomatous lesions, caused by MOTT (Mycobacteria Other Than Tuberculosis) or atypical mycobacteria, which characteristic is the disorganization of the cellular layers, the absence of fibrous capsule and necrotic center, bring, when identified, another epidemiological meaning; by these characteristics the presence of high mycobacterial load is frequent (Arckermann, 2013). Despite that, Bolaños et al. (2017) emphasizes that these atypical mycobacteria present no risk to the immunocompetent population. However, it should be noted that the number of people with debilitating diseases with neoplastic, metabolic, autoimmune and infectious origins has increased. Approximately 36,7 million people worldwide are infected with HIV (Human Immunodeficiency Virus), being carriers of AIDS (Acquired Immunodeficiency Syndrome), and in Brazil, from 2007 to 2017, about 195 thousand people are infected (UnAids, 2017; Brasil, 2017). According to UNAIDS, tuberculosis (M. tuberculosis complex) is still the leading cause of death (1:3) in this population. Despite this, MOTTs represent a danger to this population, so infected animal populations or even contaminated food are considered a potential risk to this population. Thus, under the "ONE HEALTH" perspective, any animal infection caused by some mycobacteria must be evaluated for control measures to be instituted. Thus, of the 48 samples, 33.33\% (16/48) were considered non-tuberculous lesion characteristics, which does not eliminate the risk to the human population.

In addition to the histopathological characterization, were identified AFB (Figure 2B) in $54.17 \%$ (26/48) of samples, distributed mainly inside Langhans giant cells or diffusely by tissue cut. França et al. (2013) observed AFB in 10.1\% (10/99) the analyzed samples. This situation is opposite to that verified in a study by Furlanetto et al. (2012), who did not find any AFB in 27 samples. Palmer et al. (2007) reported that certain lesions may contain small amounts of bacilli, which makes it difficult to identify the AFB. Different percentages of positive results can be found in the detection of AFB by ZN staining, varying between 17.9\% (Varello et al., 2008) and 36.8\% (Laisse et al., 2011).

Varello et al. (2008) infer that the detection of AFB has high specificity despite its low sensitivity and, when associated with the histopathological characterization of the lesions, which has high sensitivity and specificity, it generates results that allow the identification of lesions typical of tuberculosis and its differentiation from others causes, making a positive association.

The low positive percentage reported by Varello et al. (2008) may be related to several situations, such as poor preservation of samples, fixation, selection of the fragment for the slides preparation, presence of contaminants, accuracy of the researcher's reading (must be thorough and read the entire slide, AFB and differences in the evolution of the lesion). Other situations to consider include the thickness of the cut, since the thinner they are, the higher are the chances of finding the AFB, and the serial analysis of the cuts. The lack of criterion and standardization of the methodology among the different authors may imply in the non-detection of the AFB in some samples, resulting in underestimated values. These facts explain the discrepancy of results found by different researchers.

The results of this study, both in the histopathological characterization and in the identification of $\mathrm{AFB}$, were close regarding the number of samples considered positive. Therefore, we note the importance of associating histopathological characterization and detection of AFB.

Although the histopathological tests do not identify the species of the agent, they can help in the determination of the infection. Thus, the identification of tissue lesions suggestive of tuberculosis during bovine post-mortem inspection, associated with $\mathrm{HE}$ and $\mathrm{ZN}$ staining, characterizing granuloma as a typical tuberculoid and the presence of AFB, respectively, bring gains in the prevention of animal and human infection by members of the $M$. tuberculosis complex, which pose a high risk to public health.

\section{Comparison of diagnostic methods}

The results and concordances among diagnostic methods used expressed by the Kappa coefficient, sensitivity, and specificity, and Youden's coefficient can be visualized in Table 1.

When comparing PCR with histopathological methods, we found that HE and ZN staining obtained, respectively, 3.2 and 2.6 times more positive samples than the PCR. Several authors (Abu Al-Soud \& Râdström, 2001; Zanini et al., 2001; Nakatani et al., 2004) have pointed out that the difficulties of direct diagnosis of the lesion are related to the evolution of the lesion, time of 
Table 1. Results and concordances expressed by the Kappa coefficient between the diagnostic methods HE, ZN, PCR-L and N-PCR, performed from lesions suggestive of bovine tuberculosis, obtained in slaughterhouses, under SIF, during post-mortem inspection.

\begin{tabular}{cccccccccccc}
\hline T1 & T2 & $\begin{array}{c}\text { P-T1 and } \\
\text { P-T2 }\end{array}$ & $\begin{array}{c}\text { N-T1 and } \\
\text { N-T2 }\end{array}$ & $\begin{array}{c}\text { P-T1 and } \\
\text { N-T2 }\end{array}$ & $\begin{array}{c}\text { N-T1 and } \\
\text { P-T2 }\end{array}$ & Total & $\mathbf{S}$ & $\mathbf{E}$ & CY & $\begin{array}{c}\text { Kappa } \\
\text { value }\end{array}$ & Agreement \\
\hline HE & ZN & 26 & 16 & 6 & 0 & 48 & 81.25 & 0.000 & -18.75 & 0.757 & Good \\
HE & PCR-L & 8 & 14 & 24 & 2 & 48 & 25.00 & 87.50 & 12.50 & 0.110 & Weak \\
HE & N-PCR & 16 & 13 & 16 & 3 & 48 & 50.00 & 81.25 & 31.25 & 0.023 & Weak \\
ZN & PCR-L & 7 & 19 & 19 & 3 & 48 & 26.92 & 86.36 & 13.28 & 0.141 & Weak \\
ZN & N-PCR & 14 & 17 & 12 & 5 & 48 & 53.84 & 77.27 & 31.11 & 0.280 & Poor \\
PCR-L & N-PCR & 10 & 29 & 0 & 9 & 48 & 100.0 & 76.31 & 76.31 & 0.000 & Weak \\
\hline
\end{tabular}

$\mathrm{Cl}=95 \%$ confidence interval. Sensitivity and specificity of test 2 in relation to test 1 and Youden coefficient $(\mathrm{CY}) . \mathrm{T}=\mathrm{Tes} ; \mathrm{P}=$ positive; $\mathrm{N}=$ negative; $\mathrm{S}=$ sensitivity; $\mathrm{E}=$ specificity; $\mathrm{HE}=$ Hematoxylin-eosin staining; ZN = Ziehl-Neelsen staining; PCR-L = PCR using DNA extracted directly from lesions suggestive of tuberculosis; N-PCR = nested-PCR.

infection, mycobacterial load, presence of DNA polymerase inhibitors (blood and other organic solvents) and also because it is a tissue with inflammatory process exacerbated, with consequent release of inflammatory mediators by the animal's cells, which may interfere with the reaction and may produce false negative results. In addition, Cardoso et al. (2009) reported that changes in DNA concentrations in the reaction may increase or decrease the sensitivity of the test as there is no pre-established pattern of the correct amounts that exhibit the best sensitivity.

The sensitivity and specificity of PCR against histopathological characterization by HE staining and the detection of AFB by ZN staining obtained close values.

The sensitivity and specificity values of nested PCR and PCR, when compared to histopathological methods, varied within small intervals. The sensitivity and specificity values of the nested PCR for histopathological characterization by HE staining and the detection of AFB by ZN staining also obtained very close values, as well as their specificity. The study by Araújo et al. (2014) allowed the authors to calculate sensitivity values of the molecular method of 76\% using the nested PCR technique. Costa et al. (2013) obtained even more promising results, reaching 100\% sensitivity and $97.7 \%$ specificity by the same technique.

It is possible to note that nested PCR has high specificity when compared to other diagnostic methods. However its sensitivity is variable, since this technique has limitations and variations in its standardization, in addition to the high confidence intervals generated by the calculation of sensitivity and specificity averages of diagnostic methods. Due to these divergences, several molecular techniques are being tested with different protocols and adjustments in the search to perfect a technique which is feasible to the common use (Cardoso et al., 2009).

The best concordance (Good) was observed between the histopathological characterization and the detection of AFB. However, these methods are not enough to identify M. bovis. Thus, by associating them with the detection of bacterial DNA, we observed a better agreement between the detection of AFB by ZN staining and detection of bacterial DNA by nested PCR.

The highest values of the Coefficient of Youden, which aim at obtaining the lowest possible proportion of classification errors (the least number of incorrect diagnoses, false negatives and false positives) were observed when associating the histopathological methods to the nested PCR. The Kappa index value and the consequent agreement between the identification of AFB (ZN) and nested PCR were better than when nested PCR was associated with the histopathological (HE) characterization.

\section{Conclusions}

The diagnosis of bovine tuberculosis by PCR from DNA extracted directly from lesions suggestive of tuberculosis is feasible, presenting promising results. However, the diagnosis should not be based solely on the identification of bacterial DNA. We suggest a multiple approach, between the identification of macroscopic lesions during the slaughter of the animals and the histopathological characterization by staining hematoxylin-eosin, the detection of AFB by ZiehlNeelsen staining and the identification of bacterial DNA, besides the clinical status of the animal 
to obtain a reliable diagnosis. The association of nested PCR to the identification of AFB was the best association among the methods studied for the diagnosis of post-mortem tuberculosis from lesions in bovine lymph nodes.

\section{Acknowledgements}

We are grateful to the veterinarians of the Federal Inspection Service (SIF) and to the slaughterhouse that gently gave samples of slaughtered cattle. We are grateful to the São Paulo Research Foundation (FAPESP) for a research grant.

\section{References}

Abu Al-Soud, W., \& Râdström, P. (1998). Capacity of nine thermo stable DNA polymerases to mediate DNA amplification in the presence of PCR-inhibiting samples. Applied and Environmental Microbiology, 64(10), 3748-3753. PMid:9758794.

Abu Al-Soud, W., \& Râdström, P. (2001). Purification and characterization of PCR-inhibitory components in blood cells. Journal of Clinical Microbiology, 39(2), 485-493. http://dx.doi.org/10.1128/JCM.39.2.485-493.2001. PMid:11158094.

Andrade, G. B., Riet-Correa, F., Milelke, P. V., Mendez, M. D. C., \& Schild, A. L. (1991). Estudo histológico e isolamento de micobactérias de lesões similares à tuberculose em bovinos no Rio Grande do Sul. Pesquisa Veterinária Brasileira, 3-4(11), 81-86.

Araújo, C. P., Osório, A. L. A. R., Jorge, K. S. G., Ramos, C. A. N., Filho, A. F. S., Vidal, C. E. S., Roxo, E., Nishibe, C., Almeida, N. F., Júnior, A. A. F., Silva, M. R., Neto, J. B., Cerqueira, V. D., Zumárraga, M., \& Araújo, F. R. (2014). Detection of Mycobacterium bovis in bovine and bubaline tissues using Nested-PCR for TBD1.PLoS One, 9(3), e91023. http://dx.doi.org/10.1371/journal.pone.0091023. PMid:24618787.

Arckermann, M. R. (2013). Inflamação e cicatrização. In M. D. McGavin \& J. F. Zachary (Eds.), Bases da Patologia em Veterinária (5a ed., pp. 89-143). Rio de Janeiro: Elsevier.

Ayele, W. Y., Neill, S. D., Zinsstag, J., Weiss, M. G., \& Pavlik, I. (2004). Bovine tuberculosis: an old disease but a new threat to Africa. The International Journal of Tuberculosis and Lung Disease, 8(8), 924-937. PMid:15305473.

Behmer, O. A., Tolosa, E. M. C., \& Freitas-Neto, A. G. (1976). Manual de técnicas para histologia normal e patológica. São Paulo: Editora da Universidade de São Paulo.

Bolaños, C. A. D., Paula, C. L., Guerra, S. T., Franco, M. M. J., \& Ribeiro, M. G. (2017). Diagnosis of mycobacteria in bovine milk: an overview. Revista do Instituto de Medicina Tropical de São Paulo, 59, e40. http://dx.doi. org/10.1590/S1678-9946201759040. PMID: 28591268.

Brasil, Ministério da Agricultura Pecuária e Abastecimento. (1952, 29 de março). Aprova o novo Regulamento da Inspeção Industrial e Sanitária de Produtos de Origem Animal (Decreto no 30.691, de 29 de março de 1952). Diário Oficial da República Federativa do Brasil.

Brasil, Ministério da Agricultura Pecuária e Abastecimento. (2000, 24 de janeiro). Instrução normativa no 3, de 17 de janeiro de 2000. Diário Oficial da República Federativa do Brasil.

Brasil. (2006). Programa Nacional de Controle e Erradicação de Brucelose e Tuberculose. Brasília: Ministério da Agricultura Pecuária e Abastecimento.

Brasil, Ministério da Agricultura Pecuária e Abastecimento. (2008). Instrução normativa no 56, de 17 de novembro de 2008. Diário Oficial da República Federativa do Brasil.

Brasil. (2008). Manual Nacional de Vigilância Laboratorial da Tuberculose e outras Micobactérias. Brasília: Departamento de Vigilância Epidemiológica, Secretaria de Vigilância em Saúde, Ministério da Saúde.

Brasil. (2017). Boletim Epidemiológico - Aids e IST. Ano V-no 1- 27a a 53a - semanas epidemiológicas - julho a dezembro de 2016 e Ano V - no 1 - O1a a 26a - semanas epidemiológicas - janeiro a junho de 2017. Brasília: Departamento de Vigilância Epidemiológica, Secretaria de Vigilância em Saúde, Ministério da Saúde.

Cardoso M.A., Cardoso R.F., Hirata R.D.C., Hirata M.H., Leite C.Q.F., Santos A.C.B., Siqueira V.L.D., Okano, W., Rocha N.S. \& Lonardoni M.V.C. (2009). Direct detection of Mycobacterium bovis in bovine lymph nodes by PCR. Zoonosis and Public Health, (56), 465-470.

Costa, P., Ferreira, A. S., Amaro, A., Albuquerque, T., Botelho, A., Couto, I., Cunha, M. V., Viveiros, M., \& Inácio, J. (2013). Enhanced detection of tuberculous mycobacteria in animal tissues using a Semi-Nested ProbeBased Real-Time PCR. PLoS One, 11(8), e81337. http://dx.doi.org/10.1371/journal.pone.0081337. PMid:24278425.

França, L. R., Cruz, J. F., Neves, V. B. F., \& Cerqueira, R. B. (2013). Prevalência e histopatologia de lesões sugestivas de tuberculose em carcaça de bovinos abatidos no Sudoeste da Bahia. Revista Brasileira de Saúdee Produção Animal, 4(14), 721-733. http://dx.doi.org/10.1590/S1519-99402013000400016.

Furlanetto, L. V., Figueiredo, E. E. S., Conte Júnior, C. A., Carvalho, R. C. T., Silva, F. G. S., Silva, J. T., Lilenbaum, W., \& Paschoalin, V. M. S. (2012). Uso de métodos complementares na inspeção post mortem de carcaças com suspeita de tuberculose bovina. Pesquisa Veterinária Brasileira, 11(32), 1138-1144. http://dx.doi.org/10.1590/ S0100-736X2012001100011.

Jones, T. C., Hurt, R. D., \& King, N. W. (2000). Patologia Veterinária (6ª ed.). São Paulo: Manole. 
Jordão-Junior, C. M. (2004). Pesquisa de micobactérias em leite de bubalinos (Dissertação de mestrado). Universidade Estadual Paulista, Araraquara.

Koneman, E. W., Allen, S. D., Janda, W. M., Schreckenberger, P. C., \& Winn Junior, W. C. (2001). Micobactérias. In E. W. Koneman, S. D. Allen, W. M. Janda, P. C. Schreckenberger \& W. C. Winn Junior (Eds.), Diagnóstico Microbiológico ( $5^{a}$ ed., pp. 903-946). Rio de Janeiro: Medsi.

Laisse, C. J. M., Gavier-Widén, D., Ramis, G., Bila, C. G., Machado, A., Quereda, J. J., Ågren, E. O., \& van Helden, P. D. (2011). Characterization of tuberculous lesions in naturally infected African buffalo (Synceruscaffer). Journal of Veterinary Diagnostic Investigation, 23(5), 1022-1027. http://dx.doi.org/10.1177/1040638711416967. PMid:21908368.

Nakatani, S. M., Burger, M., Assef, M. C., Brockelt, S. R., Cogo, L. L., \& Messias-Reason, I. J. (2004). Efficient method for mycobacterial DNA extraction in blood cultures aids rapid PCR identification of Mycobacterium tuberculosis and Mycobacterium avium. European Journal of Clinical Microbiology \& Infectious Diseases, 23(11), 851-854. http://dx.doi.org/10.1007/s10096-004-1236-z. PMid:15558344.

Palmer, M. V., Waters, W. R., \& Thacker, T. C. (2007). Lesion development and immunohistochemical changes in granulomas from cattle experimentally infected with Mycobacterium bovis. Veterinary Pathology, 44(6), 863-874. http://dx.doi.org/10.1354/vp.44-6-863. PMid:18039899.

Pereira M.G. (2002). Epidemiologia - teoria e prática. Rio de Janeiro: Guanabara Koogan.

Portillo-Gómez, L., Morris, S. L., \& Panduro, A. (2000). Rapid and efficient detection of extra-pulmonary Mycobacterium tuberculosis by PCR analysis. The International Journal of Tuberculosis and Lung Disease, 4(4), 361-370. PMid:10777087.

Rebollo, M. J., San Juan Garrido, R., Folgueira, D., Palenque, E., Díaz-Pedroche, C., Lumbreras, C., \& Aguado, J. M. (2006). Blood and urine samples as useful sources for the direct detection of tuberculosis by polymerase chain reaction. Diagnostic Microbiology and Infectious Disease, 2(56), 141-146. http://dx.doi.org/10.1016/j. diagmicrobio.2006.03.018. PMid:16698218.

Rodriguez, J. G., Mejia, G. A., Del Portillo, P., Patarroyo, M. E., \& Murillo, L. A. (1995). Species-specific identification of Mycobacterium bovis by PCR. Microbiology, 141(Pt 9), 131-2138. http://dx.doi.org/10.1099/13500872-141-92131. PMid:7496524.

Roring, S., Hughes, M. S., Skuce, R. A., \& Neill, S. D. (2000). Simultaneous detection and strain differentiation of Mycobacterium bovis directly from bovine tissue specimens by spoligotyping. Veterinary Microbiology, 74(3), 227-236. http://dx.doi.org/10.1016/S0378-1135(00)00189-9. PMid:10808091.

Sambrook, J., \& Russel, D. W. (2001). Molecular cloning: a laboratory manual (3rd ed.). Londres: CSHL Press.

Schrader, C., Schielke, A., Ellerbroek, L., \& Johne, R. (2012). PCR inhibitors - occurrence, properties and removal. Journal of Applied Microbiology, 113(5), 1014-1023. http://dx.doi.org/10.1111/j.1365-2672.2012.05384.x. PMid:22747964.

Taylor G.M., Worth D.R., Palmer SI., Jahans K. \& Hewinson R.G. (2007). Rapid detection of Mycobacterium bovis DNA in cattle lymphnodes with visible lesions using PCR. BioMed Central Veterinary Research, 12(3), 12. http://dx.doi.org/10.1186/1746-6148-3-12.

Taylor, M. J., Hughes, M. S., Skuce, R. A., \& Neill, S. D. (2001). Detection of Mycobacterium bovis in bovine clinical specimens using real-time fluorescence and fluorescence resonance energy transfer probe rapid-cycle PCR. Journal of Clinical Microbiology, 4(39), 1272-1278. http://dx.doi.org/10.1128/JCM.39.4.1272-1278.2001. PMid:11283040.

Taylor, R. N. (1992). Measurement of variation and significance in serological test. USA: Academic Press.

Thrusfield, M. V. (2005). Epidemiologia veterinária (2 ed.). São Paulo: Roca.

UnAids. (2017). Resumo Informativo. Dia mundial contra a Aids 2017 - Estatísticas globais sobre HIV. Brasília: UNAIDS no Brasil.

Ungar, M. L., \& Germano, P. M. L. (1992). Prevalência da cisticercose bovina no Estado de São Paulo (Brasil). Revista de Saude Publica,26(3), 167-172. http://dx.doi.org/10.1590/S0034-89101992000300007. PMid:1342497.

Varello, K., Pezzolato, M., Mascarino, D., Ingravalle, F., Caramelli, M., \& Bozzetta, E. (2008). Comparison of histological techniques for the diagnosis of bovine tuberculosis in the framework of eradication programs. Journal of Veterinary Diagnostic Investigation, 20(2), 164-169. http://dx.doi.org/10.1177/10406387080200020 4. PMid:18319428.

Zanini, M. S., Moreira, E. C., Lopes, M. T. P., Oliveira, R. S., Leão, S. C., Fioravanti, R. L., Roxo, E., Zumárraga, M., Romano, M. I., Cataldi, A., \& Salas, C. E. (2001). Mycobacterium bovis: polymerase chain reaction identification in bovine lymphonode biopsies and genotyping in isolates from southeast Brazil by spoligotyping and restriction fragment length polymorphism. Memorias do Instituto Oswaldo Cruz, 6(96), 2809-2813. PMid:11562707. 